\title{
RESEARCH ON THE POSSIBILITY OF TREATING STREPTOCOCCAL INFECTIONS WITH HYPERBARIC OXYGENATION
}

Władysław Wolański

Institute of Marine Medicine Military Medical Academy, Gdynia, Poland

\section{ABSTRACT}

The aim of the study was to determine the effect of the application of hyperbaric oxygen therapy on the course of an infection with group A type T-3 hemolytic $\beta$ streptococcus. Experiments were carried out on Porton white mice and in vitro blood plates. General and local infections with streptococci were induced in animals. The infected animals were treated with hyperbaric oxygenation. The lethal effect of infection was significantly inhibited using hyperbaric oxygenation on the first and second day following the infection.

Keywords: streptococcus, mouse, general infection, local infection, hyperbaric therapy.

\section{ARTICLE INFO}

PolHypRes 2020 Vol. 70 Issue 1 pp. $43-46$

ISSN: $1734-7009$ elSSN: $2084-0535$

DOI: $10.2478 /$ phr-2020-0003

Pages: 4, figures: 0, tables: 1

page www of the periodical: www.phr.net.pl

Publisher

Polish Hyperbaric Medicine and Technology Society

\section{Original article}

Submission date: 19.01.2020 r.

Acceptance for print: 01.02.2020 r. 


\section{INTRODUCTION}

The use of hyperbaric oxygenation for therapeutic purposes has recently been developed in many different medical centres. Similarly, numerous authors have studied the influence of hyperbaric oxygenation on microorganisms, the course of infection and immune reactions in humans and experimental $[1,2,3,4,5]$.

Following a period of enthusiasm and multiple recommendations for the treatment of various diseases with oxygen hyperbaria, indications and contraindications for the use of this treatment method have now been clarified. The best results in the treatment of infections with hyperbaric oxygen are obtained in the treatment of gas gangrene (Clostridium perfringens) and in the treatment of superficial infections following trauma $[6,4,5]$.

In a literature review prepared by Gottlieb in 1971 [3], concerning studies on the influence of oxygen hyperbaria above 1.3 ATA $\mathrm{O}_{2}$ on microorganisms, a number of authors found in most cases the inhibitory effect of oxygen on microbial growth in vitro - especially Escherichia coli, Staphylococcus aureus and Pseudomonas aeruginosa. At the same time, different susceptibility of bacteria to inhibit the growth of aerobic hyperbaria was found, depending on the species and type of bacteria.

It is known from the literature that beneficial effects of treatment with hyperbaric oxygenation could be obtained also in streptococcal infections [7]. It should be noted that research on the influence of hyperbaric oxygenation in streptococcal infections is scarce in the world [8].

For this reason, experimental studies have been undertaken on the effect of hyperbaric oxygen on the development of streptococcal infection in experimental animals.

\section{MATERIAL AND METHOD}

The study was carried out on Porton white mice (females and males weighing 25-30 grams), which were infected intraperitoneally in order to induce general infection with an 18-hour broth culture on Todd-Hevitt's broth with group A type T-3 $\beta$ hemolytic streptococci in a strictly defined dose of microorganisms calculated on the given number of streptococci cultures.

Infected mice were divided into several groups and treated with hyperbaric oxygen at 2.8 ATA $\mathrm{O}_{2}$, used in 5 hyperbaric sessions on three consecutive days. On day 1 , two sessions of 90 minutes each were applied at 4-hour intervals, on day 2, and on day 3, 1 session as above.

Animals divided into four groups were treated as follows: first group after 24 hours, second group after 48 , third group after 72 and fourth group after 96 hours from infection. For each group an equally large control group was created in which no treatments were performed.

In the course of infection and treatment control the animals were subjected to animal autopsy, and bacteriological cultures on streptococcus isolation media and histological examinations of lungs, heart, kidneys and liver were performed. The isolated streptococci were examined in terms of physiological properties.

Studies are currently being carried out on the effects of oxygen hyperbaria in the case of local infections in guinea pigs.

In the course of the study, the influence of aerobic hyperbaria on the tested strain of streptococcus on the blood plate was also studied, after exposure of 90 minutes $\mathrm{O}_{2}$ and pressure of $2.8 \mathrm{ATA} \mathrm{O}_{2}$ (after 24 hours of cultivation in an incubator at $37^{\circ} \mathrm{C}$ ).

\section{RESULTS}

Animal mortality depending on the time of treatment.

Group treated after 24 Group treated after 48 Group treated after 72 Group treated after 96

hours hours hours hours

\begin{tabular}{|c|c|c|c|c|c|c|c|}
\hline Hb.T & control & Hb.T & control & Hb.T & Hb.T & control & Hb.T \\
\hline 30 & 50 & 26.6 & 26.6 & $\begin{array}{l}\% \text { of dead } \\
\text { animals }\end{array}$ & 30 & 50 & 26.6 \\
\hline
\end{tabular}

In the course of the study, the incidence of liver abscesses was also observed in animals treated and not treated with oxygen hyperbaria - more frequent liver abscesses were observed in animals not treated with oxygen hyperbaria.

It should be added that by testing group A hemolytic streptocococci on blood plates, bacterial growth inhibition was found on those exposed to hyperbaric oxygenation, which is in line with the results of other researchers 5 . In addition, these colonies showed a barely marked $\beta$ hemolysis sphere (smaller than in the control group), with no changes in the Griffith test (agglutination with specific sera) and in biochemical tests.

\section{Conclusions}

On the basis of the studies carried out in mice with general infections, a more favourable therapeutic effect was observed in cases where treatment with hyperbaric oxygenation was initiated early ( 24 hours). Later on, hyperbaric oxygenation treatment was followed by rapid development of the infection in the animals, and sometimes the opposite effect was observed consisting in faster death of treated animals. Liver abscesses have been found more frequently in animals not being treated with hyperbaric oxygen therapy. 


\section{REFERENCES}

1. Boerema J., Brummelkamp W., Meijne N. (eds.) - Clinical Application of Hyperbaric Oxygen. Prec. of the First Ist. Congr. September 1963. Amsterdam, London, New York:

2. Tooley A., Watt J. - Hyperbaric oxygen therapy: Reviev of the present position and experience in the management of Navel patients. J. Rey. Nav. Med. Serv. 1968. Vol. 54:101-130;

3. Gottlieb S. - Effect of hyperbaria oxygen on microorganisms. Ann. Rev. Microb. 1971. 25:111-152

4. Moretti G., Fontanesi S., Ghittoni L. - Prospettive attuali di impiego della ossigenaterapia iperbarica. Ann. di Med. Nav. e Trop. 1973. LXXVIII 1:11-32;

5. Ulewicz K. - The use of hyperbaric oxygen in the treatment of infections. In: The basics of hyperbaric therapy. Eds. T. Doboszyński and T. Orłowski. Gdynia 1977.

6. Schreiner H. - Quantitative evaluation of effects of hyperbaric oxygen and antibiotic drugs on Staphylococcus. w Hyperbaric Oxygenation Prec. of the Second Int. Congr. ed. by J. Mc A, Ledingham. 1965. Edinboutgh and London;

7. Mc Allister T., Stark J., Ross R. - Hyperbaric oxygen and aerobic microorganisms, w Hyperbaric Oxygenation. Prec. of the Second Int. Congr. od. by J.Mc A. Ledingham. 1965. Edinbourgh and London;

8. Rotta J. - Streptococcus pyogenes. Scientific Information. 5/74. Prague 1974;

Władysław Wolański

Instytut Medycyny Morskiej

Wojskowej Akademii Medycznej w Gdyni 